\title{
Controls on the distribution of nummulite facies: a case study from the late ypresian el garia formation (Kesra Plateau, Central Tunisia)
}

\author{
S. Jorry ${ }^{1,{ }^{*}}$, E. Davaud ${ }^{1}$ and B. Caline ${ }^{2}$ \\ ${ }^{1}$ University of Geneva, Section of Earth Sciences, Department of Geology and Palaeontology, 13 rue des \\ Maraîchers, 1205 Geneva 4, Switzerland. \\ 2 Total Exploration Production, CSTJF, Avenue Larribau, 64000 Pau, France \\ *: Corresponding author : S. Jorry, email address : Stephan.Jorry@terre.unige.ch
}

\begin{abstract}
:
Eocene nummulite deposits along the southern Tethys margin locally constitute important hydrocarbon reservoir rocks. In order to understand the heterogeneity of these complex reservoirs, we have carried out a detailed field study of the nummulite limestones which crop out at the Kesra Plateau in Central Tunisia. The main contributions of this paper can be summarised as follows:
\end{abstract}

1. Various species of Nummulites and planktonic foraminifera were identified in late Ypresian carbonates in the Kesra area and provided accurate biostratigraphic ages. Nummulitic limestones occur in the Chouabine and El Garia Formations representing deposition over a period of about 2Ma.

2. Six depositional facies have been identified in the El Garia Formation, ranging from high-energy nummulitic grainstones to laterally-equivalent lower-energy nummulithoclastic accumulations. Variations in nummulite morphology (size and shape) have been used to distinguish a number of subfacies which correspond to different depositional environments. We provide evidence that nummulite accumulations were locally sub-aerially exposed.

3. A 3D reconstruction of the Kesra Plateau outcrop identified two stacked nummulite bodies, deposited under high-energy conditions, which pass laterally into two isolated bodies in more distal parts of the platform.

4. Regional-scale observations indicate that the geometry of the Late Ypresian nummulite platform was strongly influenced by the presence of the Oued Bahloul anticline structure, which formed a major environmental barrier between open-marine and more restricted settings. Facies distribution in the Kesra area was strongly controlled by the inherited topography, which reflects the reactivation of NWSE trending faults during the Late Cretaceous and Palaeocene.

5. A tentative 3D facies model illustrates the relationship between facies and fault distributions in the Kesra area. The facies map shows that the best reservoir potential is associated with palaeo-highs, and consists of nummulite limestones deposited in very shallow waters (a few metres) under highenergy conditions. 


\section{Introduction}

Along the southern Tethys margin, an Early Eocene nummulite platform covered the area between Central Tunisia and the Gulf of Gabès (Bishop, 1988; Zaïer et al., 1998). This platform generated significant volumes of sediments mainly comprising nummulites and siltgrade nummulithoclastic debris. In Tunisia and Libya, significant oil production comes from nummulite limestone reservoirs, for example at the giant Bourri field offshore NW Libya which has reserves of 1,000-3,000MM brl oil (Racey et al., 2001). Previous studies have shown that producing nummulitic reservoirs are located preferentially on structural highs e.g. at Bourri and Al Jurf offshore Libya; at Sidi el Itayem onshore Tunisia (Hasler et al., in press); and at Ashtart (Loucks et al., 1998) and Hasdrubal (Racey et al., 2001) offshore

Tunisia.

Understanding the relationship between palaeo-topography, syn-sedimentary deformation, and "in-situ" production and preservation of nummulitic sediments depends on studies of carefully-selected outcrop analogues. Vennin et al. (2003) studied Ypresian nummulitic carbonates at outcrop some $25 \mathrm{~km}$ away at Djebel Ousselat, elaborating a three-dimensional high resolution sequence stratigraphic model for Ypresian nummulitic reservoirs. In the present paper, we present some of the results of a recent outcrop study which focussed on the Kesra Plateau of Central Tunisia, an area which constituted a structural high during the Early Eocene (Jauzein, 1967). Continuous, well-exposed outcrops here allowed nummulite facies to be mapped in detail and nummulite bodies to be delineated in terms of stratigraphic architecture, geometry and internal heterogeneity. We were able to study vertical and lateral facies distributions on the scale of a subsurface reservoir $(6 \mathrm{~km} \times 8 \mathrm{~km})$. This study is intended to contribute to improved reservoir prediction in the Libyan offshore, and in particular to the C137 licence area operated by Total.

The depositional environment of nummulite accumulations is often difficult to interpret because nummulite palaeoecology is poorly understood (see Racey, 2001 for a recent review). 
Present-day settings can rarely be used as analogues and no comparable deposits in modern environments have been documented. Another difficulty derives from the rarity of highenergy depositional structures in these grain-supported sedimentary rocks. Several authors have suggested that post-depositional bioturbation may significantly modify original fabrics (Loucks et al., 1998; Racey, 2001). In the Kesra area, the absence of red algae associated with the nummulites also makes the interpretation of depositional environments somewhat problematic.

\section{MATERIALS AND METHODS}

The Kesra Plateau is located in Central Tunisia (Fig. 1), close to the Kef el Garia outcrop locality where the stratotype of the Early Eocene El Garia Formation is exposed (Fournié, 1978). Twenty-four field sections were examined at Kesra, and 13 additional sections were detailed nearby. Biostratigraphic data were based on the identification of planktonic foraminifera and nummulites. Some 240 thin sections were analysed in order to interpret carbonate textures, faunal contents and diagenetic features (porosity, cementation, dissolution, compaction). The study of diagenetic events was complemented by cathodo-luminescence and fluid inclusions analyses.

Correlations between field sections relied on the identification of major stratigraphic boundaries, and the establishment of a 2D stratigraphic architecture from outcrop studies. 3D visualisation of the correlated profiles was based on the integration of data from logged stratigraphic sections, 2D outcrops and subsequent 3D modelling.

\section{GEOLOGICAL SETTING}

In Tunisia, the Early Eocene El Garia Formation is part of the Metlaoui Group (Fig. 2), whose regional stratigraphy has been studied by Fournié (1975, 1978), Bishop (1985, 1988), Moody (1987), Moody et al. (1989) and Dridi et al. (1991). At the base of the Group are the phosphate-rich limestones of the Chouabine Formation. Overlying are time-equivalent units of Ypresian age comprising the Faid Formation (a continental facies with evaporites); the Ain Merhotta Formation (lagoonal gastropod-rich carbonates); the El Garia Formation (nummulitic limestones); and the basinal Bou Dabbous Formation (lime mudstones). The Ousselat Member (Moody et al., 1989) represents nummulithoclastic accumulations in the El Garia Formation. 
Based on outcrop studies in Central and offshore Tunisia, Loucks et al. (1998) proposed a general facies model for the Metlaoui Group which envisages a homoclinal ramp with no sharp breaks in slope. El Garia nummulitic accumulations were deposited in a mid-ramp setting under low-energy and low-light conditions. These authors did not recognise subfacies divisions within the nummulitic accumulations.

\section{Lithostratigraphy of outcropping rocks}

In the Kesra area, five formations were recognised at outcrop (Fig. 3):

(i) At the base is the Campanian Aleg Formation characterised by greenish shales interbedded with thin limestones. The upper part of the formation is strongly deformed by normal faults and slumps.

(ii). These shale gradually pass upward into the lime mudstones of the Maastrichtian Abiod Formation. In the study area, the top of this formation is characterised by a well-developed semi-lithified hardground containing borings and burrows locally infilled by glauconite and phosphate pebbles. This surface represents a major angular unconformity on top of which rests the late Ypresian succession.

(iii) The Chouabine Formation forms the base of the cliffs delimiting the Kesra Plateau and can be divided into two units:

At its base, glauconite marls form a ledge in the outcropping topography. They are strongly bioturbated and contain abundant iron oxide concretions. This unit has been dated by R. Wernli (Geneva University) on the basis of planktonic foraminifera. The following species were identified: Morozovella subbotinae, Morozovella aragonensis, Morozovella formosa formosa, Morozovella aff. caucasica, Morozovella lensiformis, Morozovella quetra, Acarinina primitiva, Acarinina pentacamerata, Acarinina broedermami, Turborotalia aff. frontosa, Globigerina linaperta, Globigerina inaequispira. Other small benthic foraminifera includeFrondicularia, Marginulina, Lenticulina, Nodosaria, Textulariidae and Cyclammina. This faunal association gives a late Ypresian age which corresponds to the P8 biozone of Serra-Kiel et al. (1998). Other planktonic foraminifera (e.g. Morozovella angulata) indicate the reworking of P3-P4 planktonic biozones within the P8 biozone. This species has also been described in Palaeocene strata in Algeria near the Tebessa Mountains (Faid, 1995).

The marly unit is overlain by bioclastic limestones which show characteristic undulating bedding surfaces, at the base of which are concentrations of phosphatic granules (centimetre size). Above are massive beds $(20-30 \mathrm{~cm}$ thick) of bioclastic wackestones containing phosphatic nodules, small gastropods, small bivalves, rare small nummulites and well- 
preserved nautiloids. The abundance and size of the nautiloids increases toward the eastern part of the Plateau, where their diameter may reach more than $30 \mathrm{~cm}$. Shells are often unbroken and are present in concentration of up to 6/sq.m. The top of this unit is marked by a bioturbated horizon with burrows similar to Thalassinoides type. Bioturbated structures are infilled by nummulites.

(iv) The nautiloid limestones of the Chouabine Formation pass up abruptly to the El Garia Formation which shows marked lateral facies variations; from west to east, nummulite grainstones/packstones pass gradually into nummulithoclast dominated deposits (Ousselat Member).

Some 180 samples of Nummulites were collected from the top of the formation. They were identified by A. Blondeau and P. Masse (Total Exploration Production) with reference to the Elf collection for the Libyan Jdeir Formation (Nummulites identified by J. Tosquella and A. Blondeau), and to the collection of A. Blondeau (Blondeau, 1972) stored at the Museum d'Histoire Naturelle (Geneva). Identifications also made reference to Schaub (1981). Six species of Nummulites were recognised from a single stratigraphic unit at different sampling locations (Fig. 4):

Nummulites perplexus SCHAUB, 1981;

Nummulites formosus DE LA HARPE, 1883 (Nummulites «operculiniforme»);

Nummulites $c f$. pomeli FISCHEUR, 1890;

Nummulites aff. pomeli FISCHEUR, 1890;

Nummulites rollandi (evoluted / caillaudi D’ARCHIAC \& HAIME, 1853);

Nummulites tenuilamellatus FISCHEUR, 1890.

This nummulite association corresponds to the boundary between the late Ypresian and the early Lutetian (Blondeau, pers. comm.).

At Kesra, we noted the occurrence of four species within the same bed ( $N$. rollandi, $N$. aff. rollandi, $N$. perplexus, $N$. tenuilamellatus). $N$. perplexus was found at the top of the El Garia Formation at the Kesra, Kef el Garia and Kef Mergueb locations. The microspheric B-form is a lenticular to discoid nummulite with a regular whorl whose thickness may reach $0.8 \mathrm{~cm}$. Twenty-five turns are observable for a radius of about $5 \mathrm{~mm}$. Meandering sutures were observed on the surface of the test. The regular, narrow whorls (from first to last turns) and the thickness (0.4 to $0.85 \mathrm{~mm}$ : Schaub, 1981) of $N$. perplexus distinguish this species from $N$. pomeli, $N$. tenuilamellatus and $N$. rollandi which have thinner tests $(<0.4 \mathrm{~mm})$ and are characterised by more and narrower whorls in the last turns. 
(v) The El Garia Formation limestones are locally capped by yellowish marls interbedded with massive oyster accumulations belonging to the Lutetian Souar Formation (Fournié, 1978). This formation is only exposed in the centre of the Kesra Plateau and near the village of El Garia (Fig.1).

\section{ANALYSIS OF DEPOSITIONAL FACIES IN THE EL GARIA FORMATION}

Based on outcrop observations, the study of 24 field sections and the petrographic analysis of 420 thin sections, six principal facies within the El Garia Formation have been distinguished. As precise nummulite morphology could not be determined in the field or in thin section, we use morphological criteria such as nummulite size (large or small) and shape (flat or robust). This scheme permitted facies descriptions from $1 \mathrm{D}$ sections and provided a basis for 2D outcrop mapping (Table 1). In general, vertical transitions between the different nummulite facies were abrupt. The six facies were as follows:

i. $\quad$ Facies 1: Large robust nummulite packstone. In this facies, large B-form nummulites are associated with large bivalves in life position; other nummulite morphologies (small robust and large flat) are well represented and large gastropods are rare. The matrix contains a high proportion of nummulithoclasts, echinoderm debris and rare scaphopods. The presence of nummulithoclasts together with mixed, randomly orientated A- and B-form nummulites and large bivalves in life position strongly suggests that this facies constitutes an autochthonous or para-autochthonous deposit. The Nummulites-gastropod association indicates the proximity of relatively restricted settings (Moody, 1987).

ii. Facies 2: Small robust nummulite grainstone/packstone. Small nummulites are dominant and are occasionally associated with serpulid bioconstructions and debris, bivalves and gastropods, flat nummulites, and echinoderm and scaphopod fragments. This facies provides evidence of granulometric sorting, as small robust nummulites are common. By comparison with modern environments, the presence of serpulid bioconstructions suggests very shallow water deposition (Fornós et al., 1997).

iii. Facies 3: Large flat nummulite grainstone/packstone. This facies has a poor associated microfauna but contains echinoderm fragments. Grainstones are characterised by imbricated, large, flat nummulites and an absence of nummulite debris in the matrix (Fig. 5). The facies is well sorted and is characterized by large-scale cross-bedding which indicates high-energy depositional conditions. 
iv. Facies 4: Small flat nummulite packstone. Nummulites are associated with Discocyclina, Operculina, echinoderm debris, scaphopod fragments and uncommon small benthic foraminifera such as Cibicididae, Textulariidae and Lenticulina. The occurrence of thin Discocyclina, Operculina and small benthic foraminifera such as Lenticulina indicates proximity to open-marine conditions. The matrix contains significant nummulithoclast particles and mud.

v. Facies 5: Operculina and nummulithoclastic packstone. Operculina are associated with common small benthic foraminifera (Bolivina, Cibicididae, Textulariidae, Lenticulina), small nummulites and common echinoderm fragments. The matrix contains a high proportion of nummulithoclastic debris. This facies forms thick, easily eroded beds which are easily recognized at outcrop and which form a good visual marker for outcrop correlation. Based on previous studies in Tunisia (Loucks et al., 1998; Racey et al., 2001), in Libya (Arni, 1965), in Spain (Eichenseer et al., 1992) and in Yugoslavia (Bignot, 1972), Operculina facies characterises a deeper-water depositional environment than nummulite facies. However, in modern environments, the foraminifera Operculina can occur with thin nummulites in deep-water environments (Hohenegger et al., 2000).

vi. Facies 6: Nummulithoclastic packstone (Ousselat Member, sensu Moody et al., 1989). This facies contains abundant small benthic foraminifera, abundant echinoderm fragments and some planktonic foraminifera. The matrix is dominantly composed of silt-sized nummulite debris, occasionally rich in organic matter and silicified material (silica nodules or silicified bioturbated horizons). This facies, locally massive and undisturbed, is generally laminated which (together with the planktonic foraminifera) suggests the deep-water deposition of material reworked from the shallow-water nummulite platform.

\section{Construction of a facies model}

A general proximal-to-distal trend based on palaeogeographic data (Bishop, 1988; Zaïer et al., 1998) has been established for the El Garia Formation and ranges from nummulite-dominated deposits to nummulithoclast accumulations. Three different facies models have in the past been proposed for the El Garia Formation. Nummulite deposits have been interpreted as bank structures (Moody, 1987; Moody et al., 1989), as low-angle ramp accumulations (Conte et al., 1974; Loucks et al., 1998), or as shoal complexes deposited in mid-ramp settings (Racey et al., 2001). All these models indicate that the depositional environments were probably highly 
variables in terms of carbonate production and sedimentary processes. A general model cannot therefore be applied for interpreting nummulite deposition throughout the entire El Garia facies belt.

In order to establish a facies model for the El Garia Formation outcropping in the Kesra area, we used a method proposed by Walker (1984) and derived from Walther's law (Walther, 1894; Middleton, 1973), based on the most frequent observed stratigraphic facies transitions. This allowed us to define the lateral distribution of depositional environments and stratigraphic sequences and their development through time as a result of transgressions and regressions. This method is useful in studies of biofacies patterns in the rock record (Harper, 1984), especially where no recent counterparts or models are available. Applying this method to the facies recognised in the Kesra Plateau (Fig. 6), we devised a theoretical shallowing-up succession from Facies 6 (nummulithoclastic packstone) to Facies 1 (large robust nummulite packstone) or 2 (small robust nummulite grainstones).

As suggested by previous authors (e.g. Arni, 1965; Conte et al., 1974; Moody et al., 1989; Loucks et al., 1998; Racey et al., 2001; Vennin et al., 2003), this model indicates that nummulithoclast bearing facies were deposited deeper than the nummulite grainstones (Fig. $6 e$ ). The small robust nummulite facies were deposited shallower than the large flat and small flat nummulite facies, which may suggest that test flattening is correlated with increasing depth. In present-day environments, this relationship has been demonstrated for foraminifera such as Operculina ammonoides (Hottinger, 1973; Pecheux, 1995), Heterostegina depressa (Hottinger, 1973), Amphisorus hemprichii and Parasorites orbitolitoides (Hohenegger et al., 2000). In the western pacific, Hohenegger et al. (2000) suggested that thick nummulite tests may provide a protection against irradiation and/or strong hydrodynamic regimes. This may explain the proximal position of the large robust nummulite facies in the theoretical facies model (Fig. 6e).

It is clear that silt-sized nummulithoclast deposits are produced by the reworking of nummulite-rich facies from more proximal zones, but processes of fragmentation remain enigmatic. The distribution of nummulite facies appears to be controlled by environmental factors (salinity, temperature, light intensity), biological processes (reproductive strategy, bioturbation) and hydrodynamic conditions. Thus, large flat nummulites, in which intraskeletal porosity may reach up to 40\%, can easily be transported (Aigner, 1985; Racey, 2001) and as a consequence the resulting deposits are allochthonous. At Kesra, metre-scale crossbedding structures in imbricated nummulite grainstones suggest reworking of nummulite-rich sediment by high-energy currents. 


\section{STRATIGRAPHIC ARCHITECTURE}

\section{Major stratigraphic surfaces}

Four major stratigraphic surfaces have been recognised in the succession studied at the Kesra Plateau (Fig. 3). These surfaces were used as guidelines for correlation and 2D outcrop mapping. The first surface is the hardground at the top of the Abiod Formation which is overlain by late Ypresian marls containing reworked Palaeocene planktonic foraminifera (P3P4 biozones). This surface corresponds to a sedimentary hiatus lasting 14Ma, and clearly shows evidence for a break in sedimentation accompanied by significant erosion before the deposition of the nummulitic limestones. Uplift of the area during Palaeocene times could explain this hiatus.

The second surface corresponds to the bioturbated interval at the top of the Chouabine Formation and occurs below the nummulite-rich facies. The presence of a few small nummulites within the nautiloid-rich Chouabine Formation suggests that nummulite carbonate production was already occurring in Central Tunisia at this time. In the Kesra area, the abrupt arrival of nummulitic limestones indicates a significant increase in sedimentation rate, which is probably correlated with a major fall in relative sea level.

The third surface occurs between the top of the El Garia Formation and the overlying Souar Formation and marks the late Ypresian - early Lutetian boundary. This surface represents the maximum geographic extent of nummulites in the Kesra area and the maximum progradation of nummulite-rich sediments toward the Bou Dabbous basin.

The final surface is located within the El Garia Formation and associated petrographic features are illustrated in Fig. 7. The surface was recognised in four field sections in the southern Kesra Plateau, and occurs within massive beds in which serpulids are occasionally very abundant. Close to this boundary, abundant dissolved cavities (1-7mm) are visible at outcrop. In thin sections, dissolved shell fragments (Fig. 7b), geotropic features with vadose silt infillings and pendant cements beneath nummulites (Fig. 7c,d) were observed, features which suggest sub-aerial exposure at this surface. Further evidence came from analyses of fluid inclusions in primary generation of calcitic cements, which are localized in pendant cements and in early syntaxial cements surrounding echinoderm fragments (Fig. 7e). Homogenisation temperatures (Th) indicate temperatures of calcite precipitation of around $45^{\circ} \mathrm{C}$. The presence of freshwater was indicated by the melting temperature of the inclusions which was $0^{\circ} \mathrm{C}$. These observations are consistent with local sub-aerial exposure of the 
nummulite platform, which appears to have been restricted to the southern part of the Kesra Plateau. This boundary evolves to an erosive marine surface toward the east.

This evidence of exposure within the El Garia Formation confirms several previous depositional models for very shallow-water nummulite bodies (Arni, 1965; Moody et al., 1989; Racey et al., 2001). For the Kesra area, the observation is consistent with Moody (1987) who drew attention to emergent islets in nummulitic facies around Nasr Allah - Djebel Cherahil.

\section{D stratigraphic architecture from outcrop studies}

Four depositional sequences have been defined between these four stratigraphic surfaces. The lowermost sequence (S1) is characterised by glauconitic marls and the nautiloid-rich unit of the Chouabine Formation. The thickness of this shallowing-up sequence varies from $4 \mathrm{~m}$ to $6 \mathrm{~m}$. It is bounded at its base by a hardground at the top of the Abiod Formation, and above by a bioturbated interval.

The base of the second sequence (S2) (Fig. 8) is marked by the occurrence of the nummulites and nummulithoclastic deposits of the El Garia Formation. The nummulite accumulations in the western part of the Kesra Plateau are $10 \mathrm{~m}$ thick and pass rapidly into nummulithoclast facies (25m thick) to the east; this thickness variation possibly suggests continuous uplift and erosion of the nummulite deposits. This lateral facies transition is gradational and intra-bed. The S2 sequence in general shallows-up as indicated by the evidence at the top for local subaerial exposure.

The base of the third sequence (S3) is characterised by the deposition of a thin argillaceous limestone horizon $(0.50 \mathrm{~m}$ thick) which is only preserved in distal parts of the platform and pinches out toward proximal locations (Fig. 8). The limestone is discontinuous and comprises a planktonic foraminiferal wackestone, indicating deep-marine deposition (S3a). In proximal areas, infillings of mouldic cavities (which result from sub-aerial exposure: Fig. 7) by nummulithoclasts could be a possible lateral equivalent of this transgressive facies. Above, sequence S3 passes up into a regressive succession (S3b), at the base of which are Operculina packstones which are widespread in the study area, and are up to $4 \mathrm{~m}$ thick in eastern locations. The Operculina facies could be interpreted as a highstand deposit; they are overlain by nummulite-bearing deposits prograding progressively toward the east. The first occurrence of large robust nummulites associated with large bivalves and gastropods marks the final stage of this shallowing-up sequence over the Kesra Plateau. The top of the sequence 
corresponds to the maximum progradation of the late Ypresian nummulite platform in this area.

The break in nummulite carbonate production recorded by sequence S3a may reflect a major eustatic change, with important modifications to environmental factors such as water turbidity, salinity and temperature. The Eocene was characterized by a major episode of global warming expressed by a $1.5 \%$ decrease in $\delta^{18} \mathrm{O}$ which peaked during the Early Eocene Climatic Optimum (EECO) at 52-50Ma (Kenneth et al., 1991; Zachos et al., 2001). This was followed by a 17Ma trend towards cooler conditions. In the Kesra area, the maximum stratigraphic extent of the nummulite species corresponds to the EECO.

\section{D modelling}

The 3D reconstruction El Garia Formation carbonates (Fig. 9) integrates data from logged stratigraphic sections and mapped 2D outcrops. The model indicates that sequence S1 does not vary significantly in term of facies composition or thickness. Sequence S2 is characterised by the deposition of nummulite facies in the west of the study area. The constant and uniform extent of nummulite-bearing deposits at the beginning of the sequence suggests that several nummulite bodies were stacked over each other without significant change of the paleocoastline and have resulted in an aggradationnal geometry. The facies pass rapidly eastwards into a facies dominated by nummulithoclasts. During the S3a transgressive phase, argillaceous limestones were deposited in more distal parts of the platform, which previously had been dominated by nummulithoclast accumulations. During this period, nummulite deposits were absent or were transported towards the SW. To the east, nummulite facies began to prograde at the beginning of sequence S3b and reached their maximum extent at the end of this sequence.

In terms of reservoir potential, two isolated, stacked nummulite bodies can clearly be identified (Fig. 9) in the SW of the study area. This area was therefore particularly suitable for nummulite growth and development, and for the deposition of nummulite-bearing sediments under high-energy conditions. A succession of storm events may have contributed to the accumulation of thick nummulite shell debris. In the Kesra area, these nummulitic bodies are affected by numerous joints, some of them are associated with pre-existing normal faults. Laterally, the nummulite bodies pass into two isolated bodies in the eastern part of the Plateau, where they interfinger with nummulithoclastic limestones of the Ousselat Member. 


\section{THE PALAEOGEOGRAPHY OF LATE YPRESIAN DEPOSITS IN THE KESRA- MAKTAR AREA}

Outcrops observations were extended to a regional scale in order to study the development of the facies belt, and exposures between Kef el Garia and Maktar (Fig. 1) were investigated. These field observations, combined with previous studies (Jauzein, 1967; Rigane, 1991), have allowed us to reconstruct the palaeogeography of the late Ypresian deposits at the beginning of nummulite deposition (Fig. 10).

The nummulite belt is approximately $10 \mathrm{~km}$ wide and is bounded in the SW by the Oued Bahloul palaeohigh where Lutetian limestones of the Souar Formation rest directly on Abiod Formation limestones. Jauzein (1967) interpreted the top of the Abiod Formation to be karstified. The thickness of the nummulite belt increases towards the NE from $5 \mathrm{~m}$ near the palaeo-high to $15 \mathrm{~m}$ near Kesra village. This thickening could be explained by continuous uplift and erosion of the area around the Oued Bahloul anticline (see below). To the NE, geometry of the nummulithoclast facies belt of the Ousselat Member outlines a narrow gulf or bay (or intra-platform basin) within the Operculina facies belt. Further to the NE, the nummulithoclast facies pass into planktonic basinal lime mudstones of the Bou Dabbous Formation.

To the south of the palaeo-high, only $2 \mathrm{~m}$ of gastropod limestones were observed, from which nummulites are absent. These limestones are assigned to the Ain Merhotta Formation (Moody, 1987). The gastropod-rich deposits are interpreted as a lagoonal facies.

At the end of El Garia carbonate deposition, the available accommodation space was entirely filled by sediments. The intra-shelf basin represented by a narrow belt of nummulithoclast deposits within the Operculina platform was progressively filled by Operculina facies and then by nummulitic limestones which prograded towards the platform/basin margin.

\section{STRUCTURAL CONTROLS ON FACIES DISTRIBUTION}

In Tunisia, rifting between the Middle Jurassic and Early Cretaceous resulted in a major NWSE oriented fault system (Mercier et al., 2000). These faults were reactivated during the Late Cretaceous in the Kesra area, where syn-sedimentary faults and slumped units are frequently observed within the Cretaceous succession. This structural instability has previously been identified by many researchers including Jauzein (1967), Burollet et al. (1982), Marie et al. (1984), Burollet et al. (1986), Zouari et al. (1990), Negra (1994) and Zaïer et al. (1998). 
The Kesra Plateau is characterized by a fault network with three major axes: east-west, NESW and NW-SE (Fig. 11). The NW-SE faults are parallel to the Cretaceous structural trend in central Tunisia. Two anticlinal structures are present in the Kesra Plateau: the Oued Balhoul anticline, from which the El Garia Formation is missing, and the Djebel Serj anticline. Palaeogeographic maps (Fig. 12) show that facies belts trend more or less parallel to the NWSE faults. This strongly suggests that facies distribution was controlled by the residual topography resulting formed by the activation of NW-SE trending faults during the Late Cretaceous. Various observations in the Kesra area suggest that this palaeotopography predated the deposition of the late Ypresian carbonates: (i) the occurrence of synsedimentary faults and slumped deposits at the top of the Late Cretaceous succession; (ii) the important sedimentary hiatus between the Abiod and the Chouabine - El Garia Formations; and (iii) the presence of post-depositional normal faults affecting the El Garia deposits.

On this inherited topography, nummulite deposits accumulated on palaeo-highs while nummulithoclasts facies tended to be concentrated within palaeo-lows. The transition with the basinal deposits of the Bou Dabbous Formation suggests a significant bathymetric change, which could be related to a major change in slope angle controlled by a NW-SE trending fault.

\section{D FACIES MODEL}

The synthetic facies model in Fig. 13 takes into account detailed facies and fault distributions observed in the Kesra Plateau area. This model contrasts with the homoclinal ramp proposed by Loucks et al. (1998), in which nummulitic packstones/grainstones were deposited in midramp settings in 30-60m of water. In our interpretation, the carbonate platform was affected by major normal faults which divided various different depositional environments. Evidence of local sub-aerial exposure and the presence of high-energy structures indicate that the nummulite facies was deposited in very shallow waters, perhaps of only a few metres. Nummulite carbonate production was focused on Cretaceous palaeo-highs, with the small robust nummulite facies deposited at crestal locations. Bars with high concentrations of large, flat imbricated nummulites formed in shallow-water locations swept by high-energy currents as indicated by the cross-bedding structures. Behind these bars were protected zones in which large robust nummulites and large bivalve packstones were deposited. In front of the nummulite bars occur small nummulite and Discocyclina packstones characterising a more open-marine environment. 
The Operculina facies marks the transition between the nummulite platform and the outerplatform environment. Nummulithoclast facies (Ousselat Member) dominated outer-platform zones and also an intra-shelf depression which formed as a result of tectonically-driven subsidence associated with local normal fault activity. The presence of fine-grained, laminated sediments rich in organic matter within this graben suggests a confined environment with reduce oxygen levels.

The pinch-out of the nummulite facies belt towards the SW, and the absence of nummulites behind the Oued Bahloul anticline, shows that this structural high formed a major environmental barrier between open-marine and a more protected setting. The protected zone is interpreted as a closed embayment. The gastropod limestones of the Ain Merhotta Formation constitute a lateral equivalent of the nummulite platform deposits to the NE.

The nummulithoclast-dominated facies within the intra-shelf basin constitutes a tight reservoir unit, but the organic matter may confer some source potential. Similar facies have been found in the D2-137N field (NW offshore Libya), and in the nearby Al Jurf field, nummulithoclastic grainstones have good reservoir characteristics. Late diagenetic dissolution or dolomitization may result in secondary porosity which could enhance reservoir potential.

\section{CONCLUSIONS}

1. We have studied a late Ypresian nummulite carbonate platform in the Kesra Plateau of central Tunisia. On the basis of new biostratigraphic data, we identify an important sedimentary hiatus between the Late Cretaceous and the late Ypresian depositional sequences. This erosional event could be explained by uplift of the Kesra Plateau during the Palaeocene.

2. Biostratigraphically-derived dates for the base of the Chouabine Formation (51Ma) and the top of the El Garia Formation (49 Ma) suggest that the nummulite carbonate interval represents about 2Ma of deposition.

3. Detailed petrographic and stratigraphic studies show that the El Garia Formation is characterised by frequent facies and thickness variations, from nummulitic packstones/grainstones in the SW to thick nummulithoclastic accumulations in the NE. Variations in nummulite morphology allow six subfacies to be defined, each associated with different depositional settings. The location of the subfacies along a generalized depositional profile varies according to nummulite morphology, by the presence of Discocyclina and Operculina, and by the proportion of nummulithoclasts in the matrix. 
4. The El Garia Formation is composed of two shallowing-up depositional sequences separated by a deepening-up sequence, which is only recorded in the deeper part of the platform. The break in nummulite carbonate production detected during this transgressive period suggests a major eustatic change.

5. 3D modelling allows the stratigraphic architecture of the nummulite bodies to be detailed. Two stacked nummulite bodies are present in proximal parts of the platform, passing into two disconnected bodies in more distal areas.

6. Regional-scale observations showed that the late Ypresian platform was strongly influenced by the presence of the Oued Bahloul anticline structure, which formed a major environmental barrier between an open-marine and a more protected settings. Facies transitions in the Kesra area appear to have been controlled by residual topography resulting from reactivation of NNW-SSE faults during the Late Cretaceous and the Palaeocene. The maximum progradation of the nummulite belt towards the NE occurs when the available accommodation space was filled within the paleo-lows (at the top of the Late Ypresian).

7. A 3D facies model is proposed to illustrate the relation between facies and fault distributions observed in the Kesra area. The facies distribution of the carbonate platform was strongly controlled by topographic irregularities, and the best potential reservoirs are located at the top of the palaeo-highs. Close to these areas, evidence of local sub-aerial exposure confirms that the nummulite reservoir facies was deposited in water depths of a few metres.

\section{ACKNOWLEDGEMENTS}

The authors would like to thank Alphonse Blondeau for the identification of the nummulites collected from Kesra, and Roland Wernli (University of Geneva) for the identification of the planktonic foraminifera. The assistance of Richard Labourdette (Total Exploration Production) for the 3D reconstruction was greatly appreciated. Pierre Masse (Total Exploration Production), Munir ben Ahmad (CPTL, Libya), Pierre Le Guern and Yves Nardini (University of Geneva) are also thanked for their help in the field. Critical comments by Philippe Charpentier (Total Exploration Production) and Herbert Heichenseer (Total Exploration Production) are acknowledged. Journal review was by Dick Moody and Andrew Racey whose comments on a previous version are acknowledged with thanks. 


\section{REFERENCES}

AIGNER, T., 1985. Biofabrics as dynamic indicators in nummulite accumulations. Journal of Sedimentary Petrology, 55, 131-134.

ARCHIAC, A. D' and HAIME, J., 1853. Description des animaux fossiles du groupe nummulitique de l'Inde, précédée d'un résumé géologique et d'une monographie des Nummulites. Paris, Gide et J. Baudry, 373 pp.

ARNI, P., 1965. L'évolution des Nummulitinae en tant que facteur de modification des dépôts littoraux. Colloque International de Micropaléontologie (Dakar), Mémoires du BRGM, 32, 7-20.

BARTHOLDY, J., BELLAS, S.M., COSOVIC, V., FUCEK, V.P. and KEUPP, H., 1999. Processes controlling Eocene mid-latitude larger foraminifera accumulations: modelling of the stratigraphic architecture of a fore-arc basin (Podhale Basin, Poland). Geologica Carpathica, 50, 6, 435-448, Bratislava.

BIGNOT, G., 1972. Recherches stratigraphiques sur les Calcaires du Crétacé supérieur et de l'Eocène d'Istrie et des régions voivines. Essai de révision du Liburien. Trav. Lab. Micropal., Paris, 2, 353pp.

BISHOP, W.F., 1985. Eocene and Upper Cretaceous carbonate reservoirs in East Central Tunisia. Oil and Gas Journal, Dec 2, 137-142.

BISHOP, W.F., 1988. Petroleum geology of East-Central Tunisia. AAPG Bull., 72 (9), 10331058.

BLONDEAU, A., 1972. Les Nummulites. Vuibert, 254pp., Paris.

BUROLLET, P.F. and DESFORGES, G., 1982. Dynamique des bassins néo-crétacés en Tunisie. Livre jub. G. Lucas, Mémoires Géologiques de l’Université de Dijon, 7, 381389.

BUROLLET, P.F. and ELLOUZ, N., 1986. L’évolution des bassins sédimentaires de la Tunisie Centrale et Orientale. Bulletin des Centres Recherche Exploration-Production Elf-Aquitaine, 10 (1), 49-68.

COMTE, D. and LEHMAN, P., 1974. Sur les carbonates de l'Yprésien et du Lutétien basal de la Tunisie Centrale. Compagnie Française des Pétroles, Notes et Mémoires, 11, 225292.

DRIDI, M. and SEJIL, A., 1991. Eocene. In: Hmidi and Sadras (Eds.) Tunisian Exploration Review. Entreprise Tunisienne d’Activités Pétrolières (ETAP), 73-93. 
EICHENSEER, H. and LUTERBACHER, H., 1992. The Marine Paleogene of the Tremp Region (NE Spain) - Depositional Sequences, Facies History, Biostratigraphy and Controlling Factors. Facies, 27, 119-152.

FAID, N., 1995. Contribution à l'étude stratigraphique de l'Eocène des Aures et des régions limitrophes (Altas Saharien, Algérie). Thèse Doct. ès. Sci., Université d'Orléans, 183pp. FISCHEUR, E., 1890. Les terrains éocènes de la Kabylie de Djurjura. Alger, 474 pp.

FORNÓS, J.J., FORTEZA, V. and MARTINEZ-TABERNER, A., 1997. Modern polychaete reefs in Western Mediterranean lagoons: Ficopomatus enigmaticus (Fauvel) in the Albufera of Menorca, Balearic Islands. Palaeogeography, Palaeoclimatology, Palaeoecology, 128, 175-186.

FOURNIÉ, D., 1975. L’analyse séquentielle et la sédimentologie de l’Yprésien de Tunisie. Bull. Cent. Rech., Pau-SNPA, 9, 27-75.

FOURNIÉ, D., 1978. Nomenclature lithostratigraphique des séries du Crétacé supérieur au Tertiaire de Tunisie. Bull. Cent. Rech. Explor.-Prod. Elf-Aquitaine, 2 (1), 97-148.

HARPE, P., de la, 1883. Monographie der in Ägypten und der lybischen Wüste vorkommenden Nummuliten. Palaeontographica, 30, 157-216.

HARPER, C.W., Jr., 1984. Improved Methods of Facies Sequence Analysis. In: Walker, R.G. (Ed.), Facies Models. Geoscience Canada, Reprint Series 1, 11-13.

HASLER, C.-A., in press. Geometry and internal discontinuities of an Ypresian carbonate reservoir (SIT oil field, Tunisia). Thèse Doct. ès. Sci., Université de Genève, Terre et Environnement.

HOHENEGGER, J., YORDANOVA, E. and HATTA, A., 2000. Remarks on West Pacific Nummulitidae (Foraminifera). Journal of Foraminiferal Research, 30 (1), 3-28.

HOTTINGER, L., 1973. Distribution of larger Peneroplidae, Borelis and Nummulitidae in the Gulf of Elat, Red Sea. Utrecht Micropaleontological Bulletin, 15, 35-110.

JAUZEIN, A., 1967. Contribution à l'étude géologique des confins de la Dorsale tunisienne. Annales des Mines et de la Géologie, 22, 475 pp.

KENNETH, J.P. and SCOTT, L.D., 1991. Abrupt deep-sea warming, palaeoceanographic changes and benthic extinctions at the end of the Paleocene. Nature, 353, 225-229.

LOUCKS, R.G., MOODY, R.T.J., BELLIS, J.K. and BROWN, A.A., 1998. Regional depositional setting and pore network systems of the El Garia Formation (Metlaoui Group, Lower Eocene), offshore Tunisia. In: Macgregor, D.S., Moody, R.T.J. and Clark-Lowes, D.D., (Eds.), Petroleum Geology of North Africa. Geol. Soc. Lond., Spec. Publ., 132, 355-374. 
MARIE, J., TROUVE, P., DESFORGES, G. and DUFAURE, P., 1984. Nouveaux éléments de paléogéographie du Crétacé de Tunisie. Notes et Mémoires, Compagnie Française des Pétroles, 19, 7-37.

MERCIER, E., FRIZON DE LAMOTTE, D., SAINT BÉZARD, B. and BRACÈNE, R., 2000. The two main steps of the Atlas building and geodynamics of the western Mediterranean. Tectonics, 19, (4), 740-761.

MIDDLETON, G.V., 1973. Johannes Walther's Law of the correlation of facies. Geological Society of America Bulletin, 84, 979-988.

MOODY, R.T.J., 1987. The Ypresian carbonates of Tunisia -- a model of foraminiferal facies distribution. In: Hart, M.B. (Ed.), Micropalaeontology of Carbonate Environments. B.M.S. Series, Ellis Horwood, Chichester, pp.82-92.

MOODY, R.T.J. and GRANT, G.G., 1989. On the importance of bioclasts in the definition of depositional model for the Metlaoui carbonate group. Actes des IIème Journées de Géologie Tunisienne Appliquée à la Recherche des Hydrocarbures, Mémoires de l'Etap, 3, 409-427.

NEGRA, H., 1994. Les dépôts de plate-forme à bassin du Crétacé supérieur en Tunisie centroseptentrionale (formation Abiod et faciès associés); stratigraphie, sédimentation, diagenèse et intérêt pétrolier. Thèse Doct. ès Sci., Université de Tunis II.

NEMKOV, G.I., 1962. Remarques sur la paléoécologie des Nummulites. Vopr. Micropaleontol., SSSR, 6, 64-72, Traduction B.R.G.M.

PECHEUX, M.J.-F., 1995. Ecomorphology of a recent large foraminifer, Operculina ammonoides. Geobios, 28, 529-566.

RACEY, A., 2001. A review of Eocene nummulite accumulations: Structure, formation and reservoir potential. Journ. Petrol. Geol., 24 (1), 79-100.

RACEY, A., BAILEY, H.W., BECKETT, D., GALLAGHER, T., HAMPTON, M.J. and McQUILKEN, J., 2001. The petroleum geology of the Early Eocene El Garia Formation, Hasdrubal field, offshore Tunisia. Journ. Petrol. Geol., 24 (1), 29-53.

RIGANE, A., 1991. Les calcaires de l'Yprésien en Tunisie centro-septentrionale : cartographie cinématique et dynamique des structures. Thèse doct. ès Sciences, Uni. Franche-Conté, $181 \mathrm{pp}$.

SCHAUB, H., 1981. Nummulites et Assilines de la Téthys Paléogène. Taxinomie, phylogenèse et biostratigraphie. Schweizerische Paläontologische Abhandlungen, 104, 105, 106. 
SERRA-KIEL, J., HOTTINGER, L., CAUS, E., DROBNE, K., FERRÀNDEZ, C., JAUHRI, A.K., LESS, G., PAVLOVEC, R., PIGNATTI, J., SAMSO, J.M., SCHAUB, H., SIREL, E., STROUGO, A., TAMBAREAU, Y., TOSQUELLA, J. and ZAKREVSKAYA, E., 1998. Larger foraminiferal biostratigraphy of Tethyan Paleocene and Eocene. Bull. Soc. Géol. France, 169, 2, 281-299.

VENNIN, E., VAN BUCHEM, F.S.P., JOSEPH, P., GAUMET, F., SONNENFELD, M., REBELLE, M., FAKHFAKH-BEN JEMIA, H. and ZIJLSTRA, H., 2003. A 3D outcrop analogue model for Ypresian nummulitic carbonate reservoirs: Jebel Ousselat, northern Tunisia. Petroleum Geoscience, 9 (2), 145-161.

WALKER, R.G., 1984. General Introduction : Facies, Facies Sequences and Facies Models. In: Walker, R.G., (Ed.): Facies Models. Geoscience Canada, Reprint Series 1, 1-9.

WALTHER, J., 1894. Einleitung in die Geologie als historische Wissenschaft. Verlag von Gustav Fischer, Jena, 3 vols., 1055 pp.

ZACHOS, J., PAGANI, M., SLOAN, L., THOMAS, E. and BILLUPS, K., 2001. Trends, Rythms, and Aberrations in Global Climate 65 Ma to Present. Science, 292, 686-693.

ZAÏER, A., BEJI-SASSI, A., SASSI, S. and MOODY, R.T.J., 1998. Basin evolution and deposition during the Early Palaeogene in Tunisia. In: Macgregor, D.S., Moody, R.T.J. and Clark-Lowes, D.D., (Eds.): Petroleum Geology of North Africa. Geol. Soc. Lond., Spec. Publ., 132, 375-393.

ZOUARI, H., TURKI, M.M. and DELTEIL, J., 1990. Nouvelles données sur l'évolution tectonique de la chaîne de Gafsa. Bull. Soc. Géol. France, 8 (VI), 621-629.

\section{CAPTIONS}

Table 1. Classification scheme for nummulite-bearing deposits used in this study, based on variations in nummulite morphology.

Fig. 1. Location map of the study area in the Kesra Plateau, Central Tunisia.

Fig. 2. Generalized stratigraphy of the Metlaoui Group (after Zaïer et al., 1998). The Faid, Ain Merhotta, El Garia and Bou Dabbous Formations represent time-equivalent lateral variation of facies along a landward-basinward depositional profile.

Fig. 3. General stratigraphy of outcropping rocks in the Kesra Plateau.

Fig. 4. Late Ypresian Nummulites species collected from the top of the El Garia Formation, Kesra Plateau. 
Fig. 5. Field photograph of a vertical transition between two nummulitic facies, here separated by an undulating erosive surface. The intervals can be distinguished in terms of nummulite contents and morphologies. Thus horizon “a” is a small robust nummulite grainstone, while "b" is a large flat nummulite grainstone.

Fig. 6. Construction of a theoretic facies model for the El Garia Formation based on the method of the most frequent stratigraphic facies transitions.

Fig. 7. Photomicrographs illustrating various characteristics of the intra-El Garia Formation stratigraphic surface (see text for details).

a,b. Photomicrograph illustrating the dissolution of large bivalve shell with infilling vadose silts and nummulithoclasts;

c. Photomicrograph showing pendant cement beneath a nummulite test.

d. Calcite pendant cement under cathodo-luminescence;

e. Detail of early syntaxial cement developed around an echinoderm fragment; fluid inclusions in this early diagenetic phase were studied and provided evidence for subaerial exposure (see text for details).

Fig. 8. 2D outcrop map of a cliff face located near the centre of the Kesra Plateau. A discontinuous horizon of argillaceous wackestone is interpreted as a transgressive facies and can be traced for several kilometres to the east. The top of the cliff is composed of small robust nummulite grainstones, which are extended progressively further eastwards over time.

Fig. 9. 3D fence diagram of the stratigraphic architecture of late Ypresian carbonates of the El Garia Formation in the Kesra Plateau.

Fig. 10. Palaeogeographic map showing the distribution of late Ypresian facies in the KesraMaktar area. Outcrops: DB: Djebel Bellouta; DbA: Djebel ben Abbes; DeA: Dir el Attaf; DM: Djebel Mansoura; DS: Djebel Serj; KeG: Kef el Garia; KeL: Kef el Lia; KM: Kef Mergueb; KP: Kesra Plateau; OB: Oued Bahloul; OK: Oued Kranga.

Fig. 11. Principal structural trends in the Kesra Plateau area.

Fig. 12. Facies distribution in the Kesra Plateau area in the context of the dominant NNWSSE fault trend.

Fig. 13. 3D facies model showing the distribution of late Ypresian carbonates in the Kesra area. 


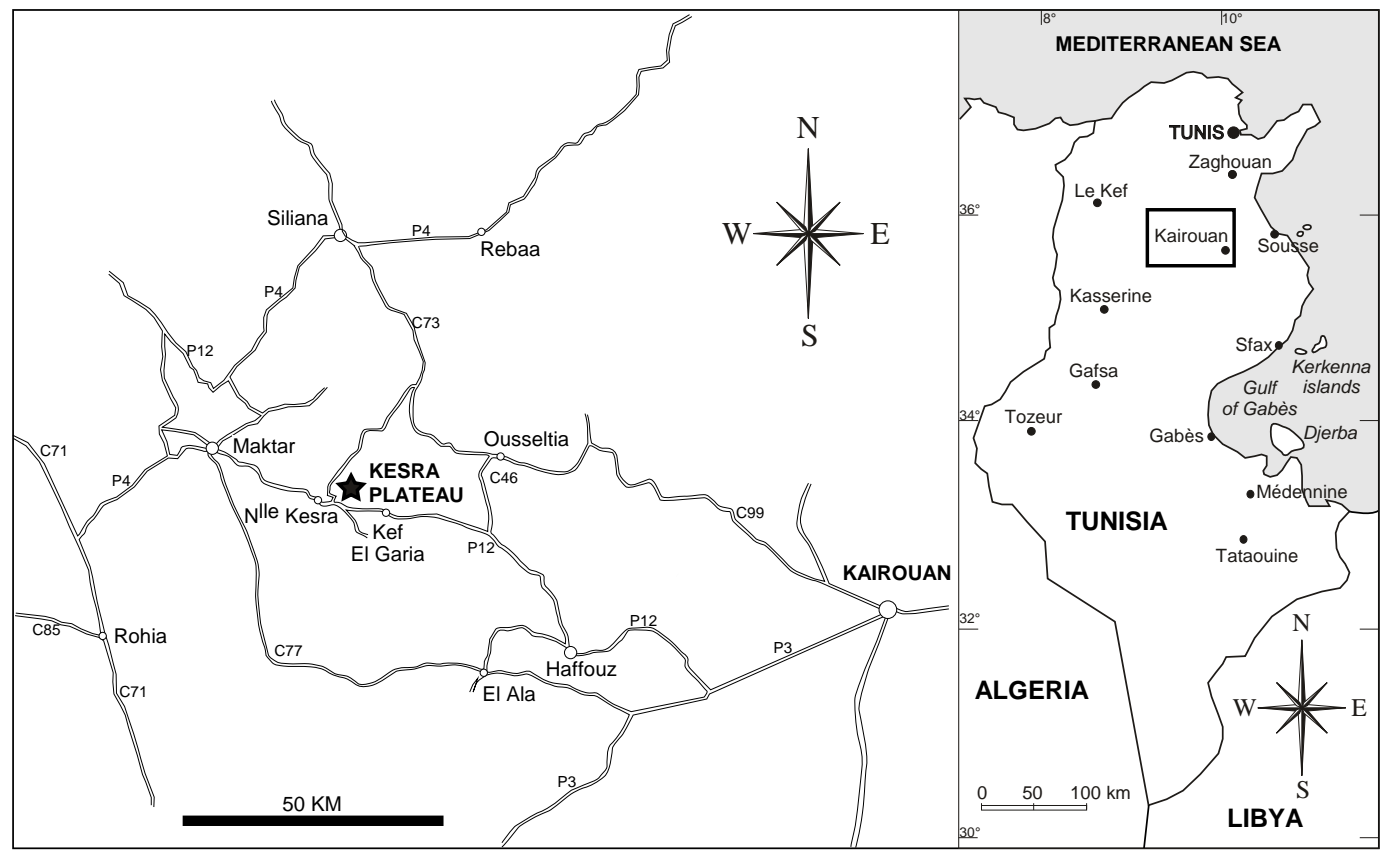


Figure 2

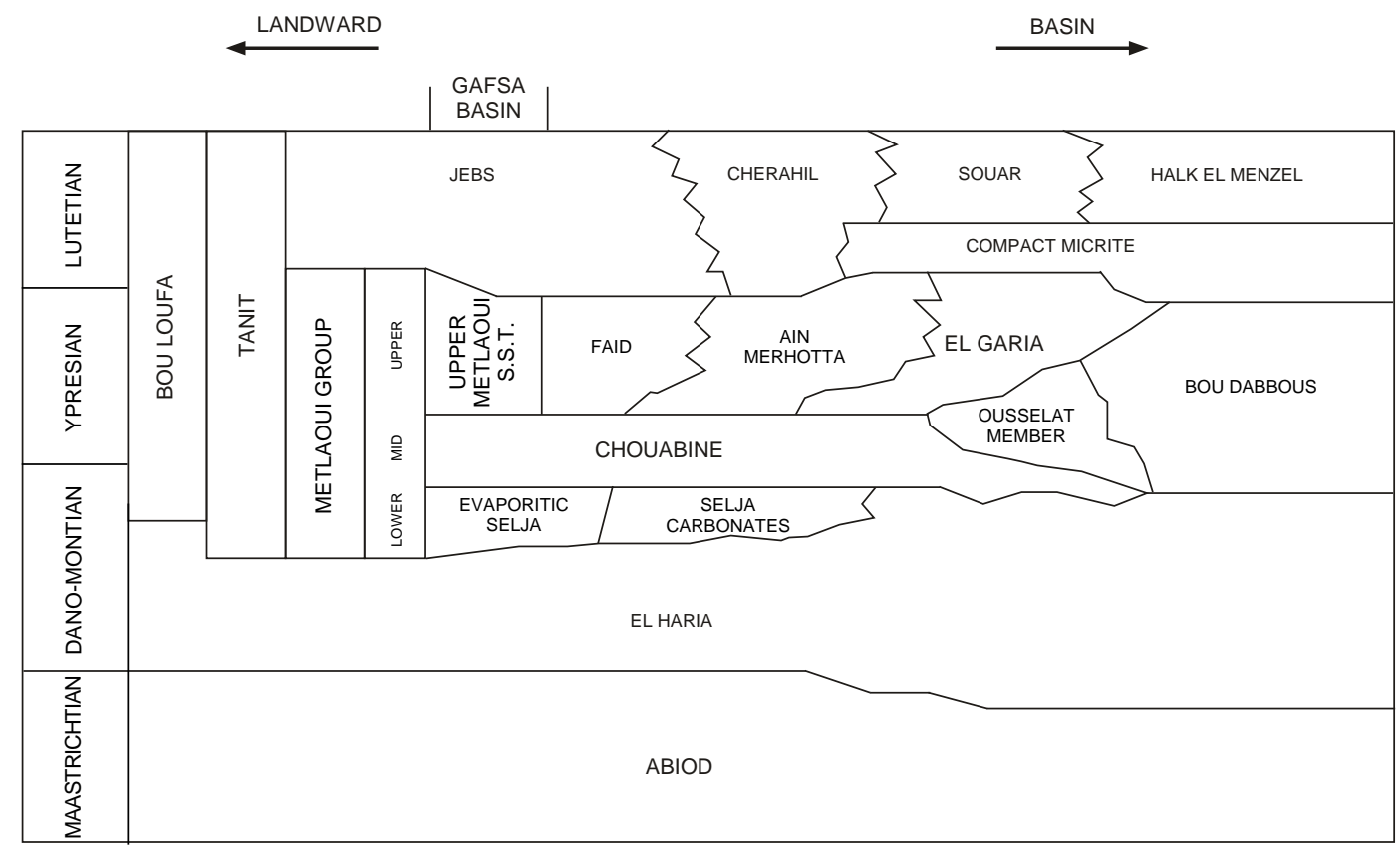




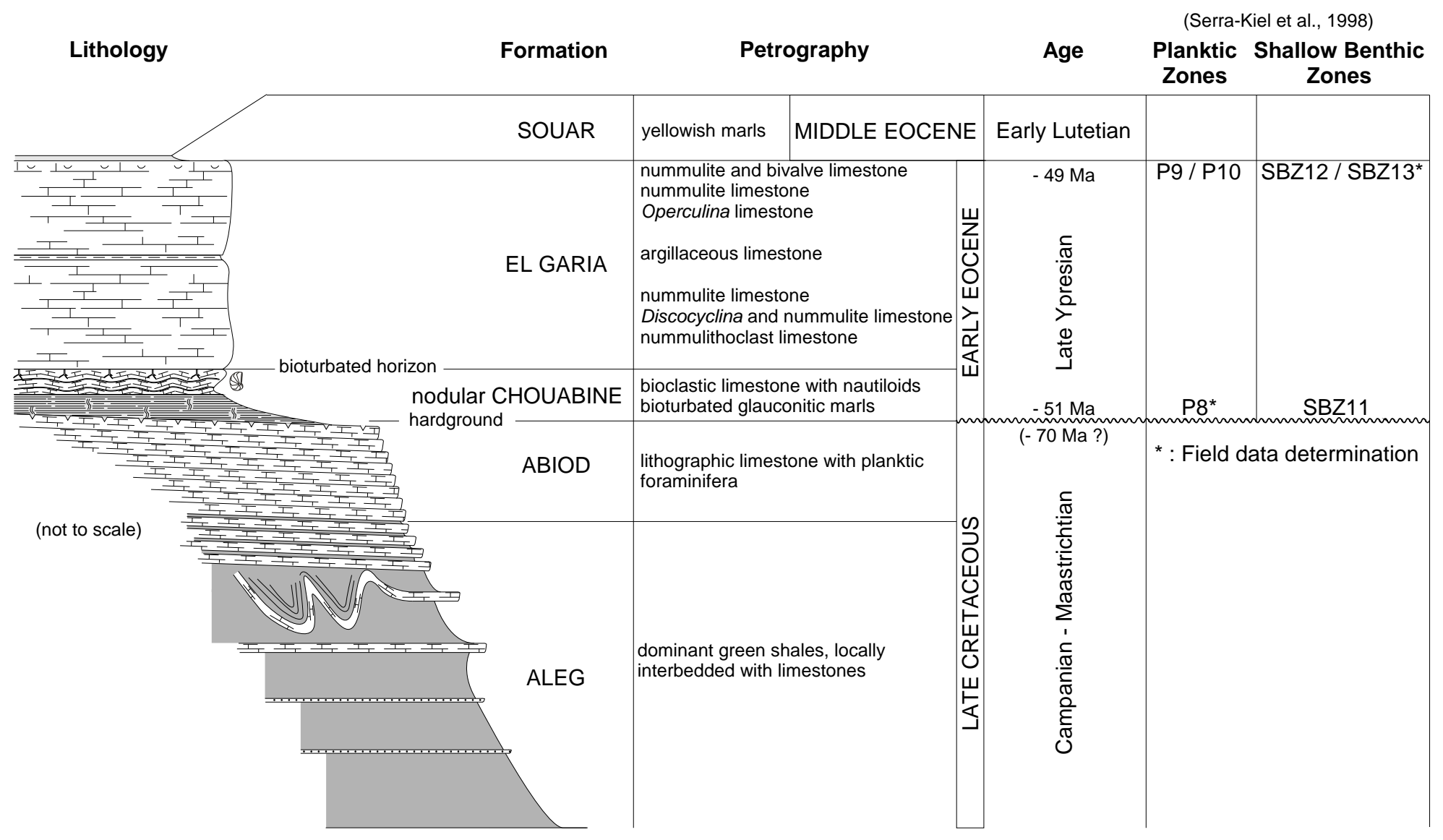



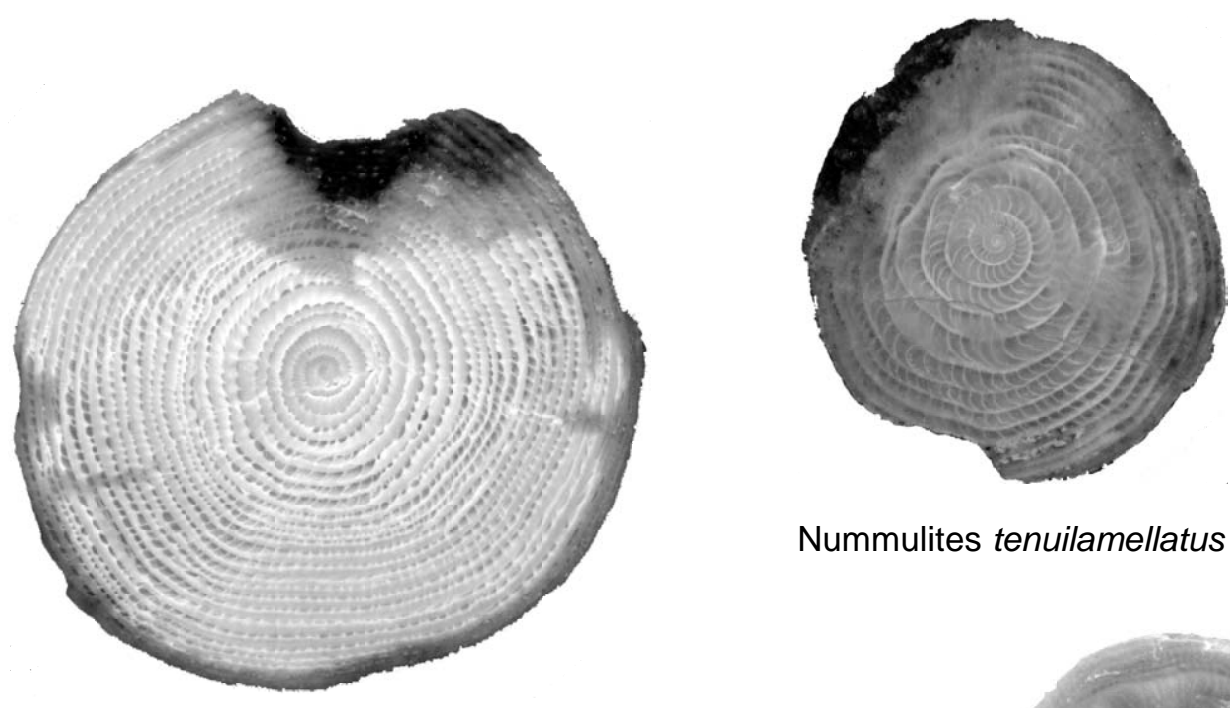

Nummulites tenuilamellatus

Nummulites perplexus

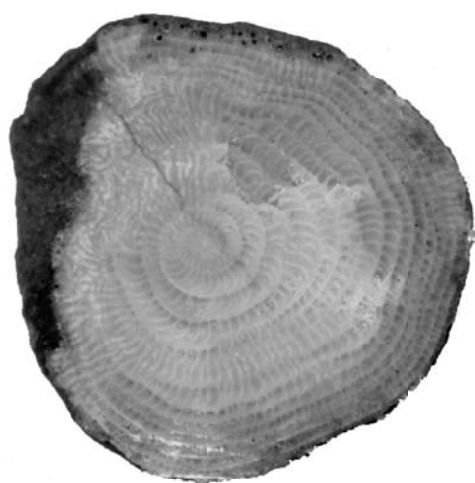

Nummulites rollandi

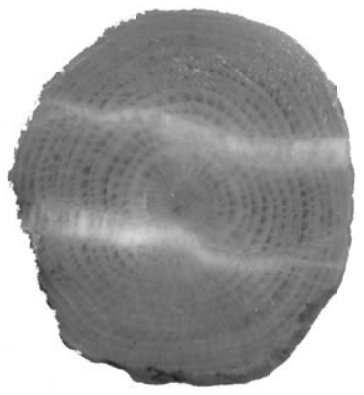

Nummulites pomeli

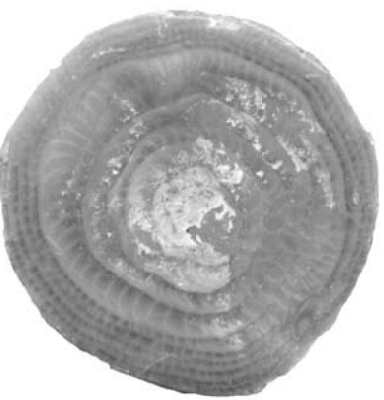

Nummulites formosus 


\begin{tabular}{|c|c|c|}
\hline & $\begin{array}{c}\mathrm{W}<1 \mathrm{~cm} \\
\text { Small Nummulites (A-forms) }\end{array}$ & $\begin{array}{c}\qquad \mathrm{W}>1 \mathrm{~cm} \\
\text { Large Nummulites (B-forms) }\end{array}$ \\
\hline 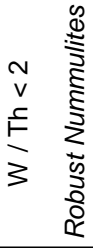 & Small Robust Nummulite & Large Robust Nummulite \\
\hline 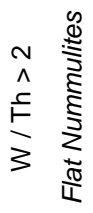 & Small Flat Nummulite & $\overbrace{\text { Large Flat Nummulite }}$ \\
\hline
\end{tabular}


Figure 5

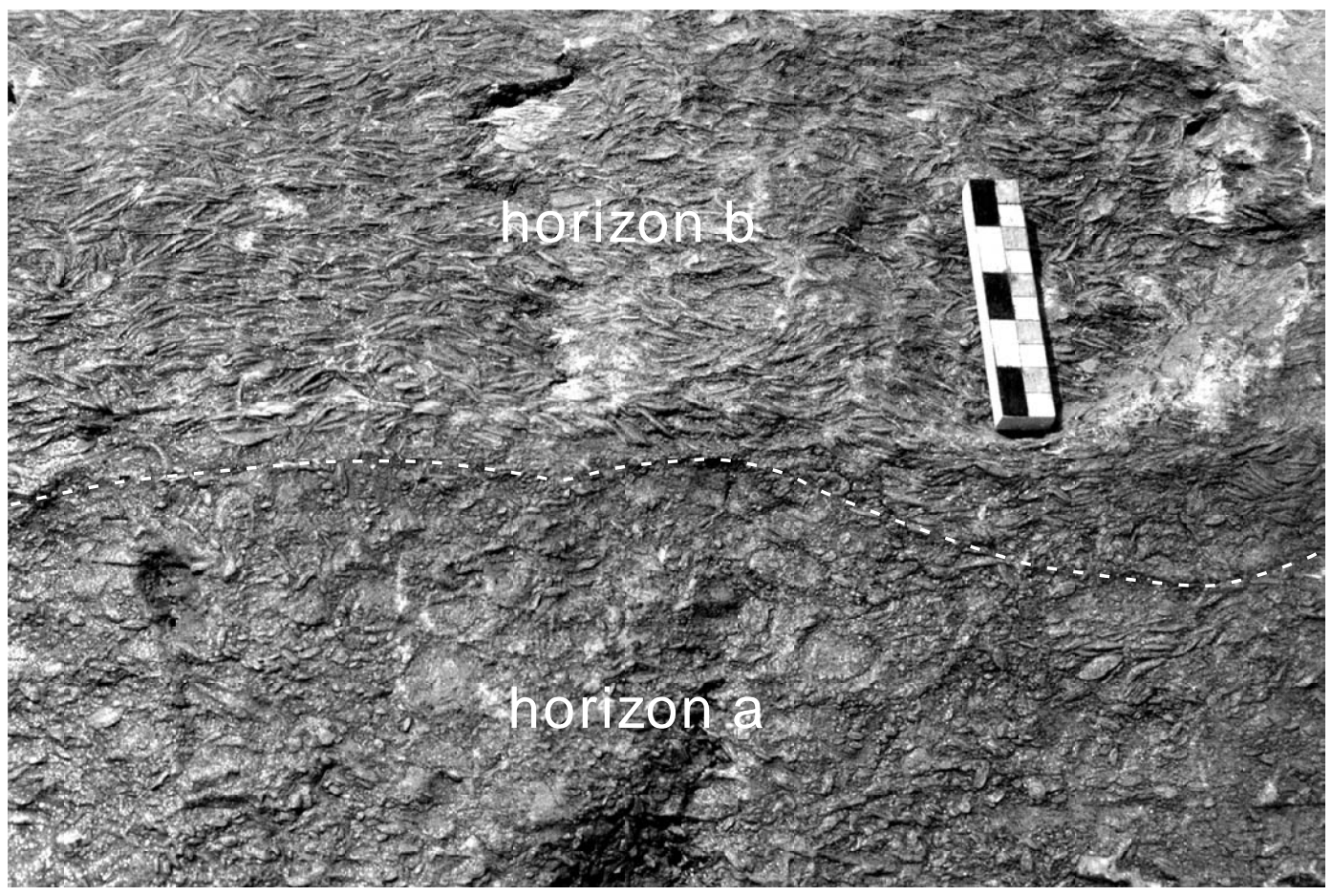




\section{(a) Transition matrix}

\section{overlying facies}

\begin{tabular}{|c|c|c|c|c|c|c|}
\hline \multirow{6}{*}{ 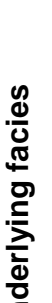 } & & 1 & 2 & 3 & 4 & 5 \\
\hline & 1 & 0 & 0 & 0 & 0 & 0 \\
\hline & 2 & 0 & 0 & 7 & 3 & 0 \\
\hline & 3 & 5 & 12 & 0 & 3 & 3 \\
\hline & 4 & 2 & 4 & 9 & 0 & 5 \\
\hline & 5 & 0 & 1 & 6 & 10 & 0 \\
\hline 5 & 6 & 0 & 0 & 1 & 1 & 21 \\
\hline
\end{tabular}

\section{b Preferential transitions statistically proved}

$\begin{array}{ccccc}\begin{array}{c}\text { facies } \\ \text { transition }\end{array} & \mathbf{P} & \mathbf{N} & \mathbf{M} & \text { Probability } \\ 2 \longrightarrow 3 & 0.17 & 10 & 7 & 0.00034 \\ 3 \longrightarrow 1 & 0.06 & 24 & 5 & 0.01168 \\ 3 \longrightarrow 2 & 0.16 & 24 & 12 & 0.00011 \\ 4 \longrightarrow 3 & 0.19 & 21 & 9 & 0.00979 \\ 5 \longrightarrow 4 & 0.18 & 28 & 10 & 0.02186 \\ 5 \longrightarrow 6 & 0.21 & 28 & 11 & 0.02022 \\ 6 \longrightarrow 5 & 0.26 & 24 & 21 & 0.00000\end{array}$

$\mathbf{P}$ transition probability for random sequence

$\mathbf{N}$ total no. of transitions from lower facies

M observed no of transition from lower to upper facies

Probability : binomial probability of $\mathrm{M}$ or more successes in $\mathrm{N}$ trials under null hypothesis (random sequence)

A probability lower than the threshold value $(0.02)$ indicates that the transition from facies a to $b$ occurs more frequently than predicted by random chance

\section{(c) Facies relationship diagram}

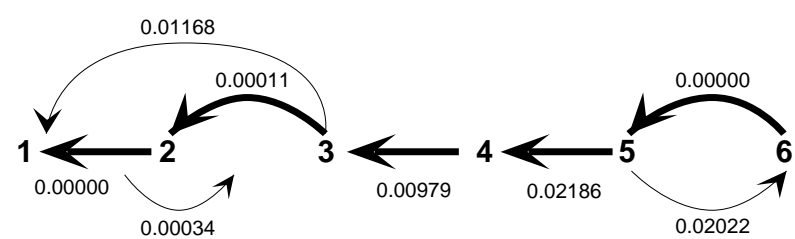

Heavy lines show significant relationships at 0.1 level

\section{(d) Theoretic shallowing-up sequence}

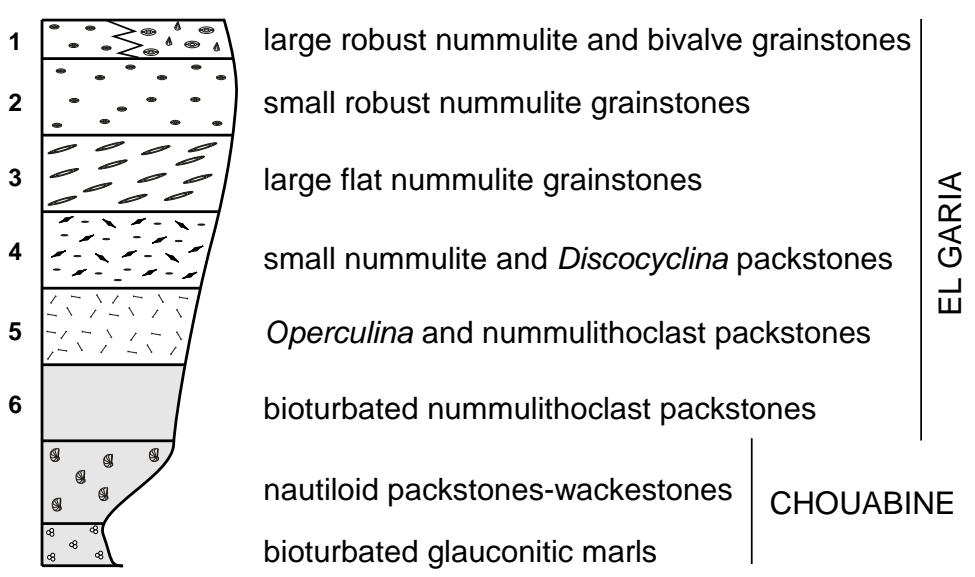

(e) Theoretic depositional model of the lateral distribution of nummulite facies of the El Garia Formation

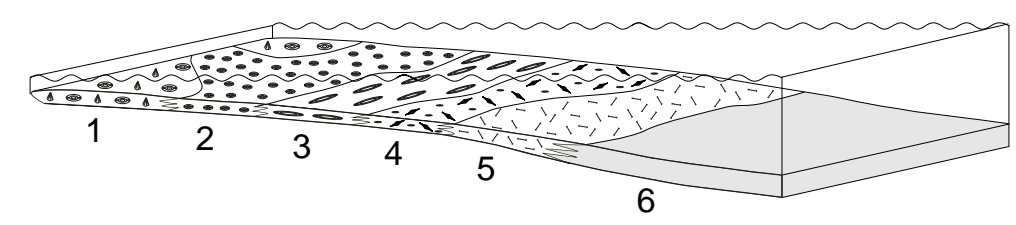



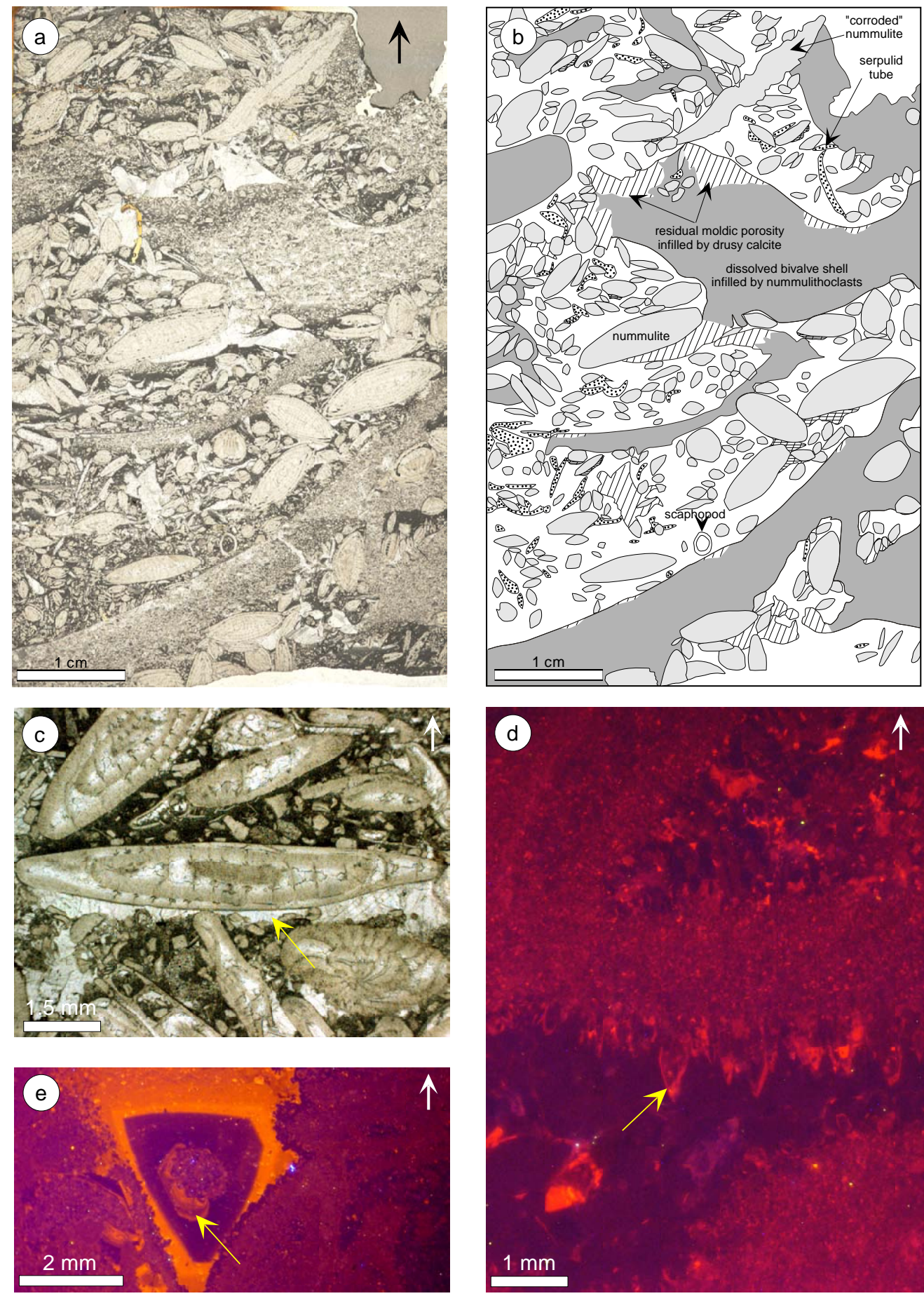
Dir Feddane el Mrassi outcrop

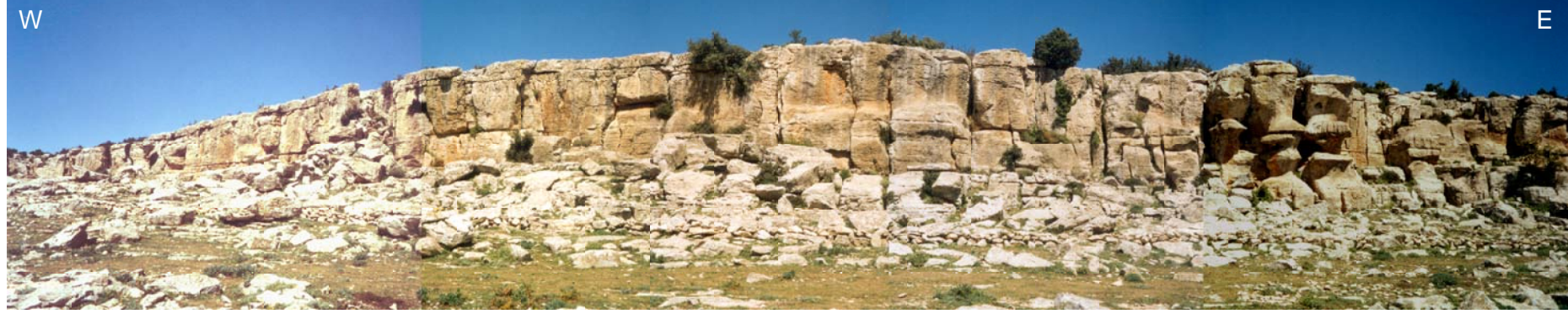

View of lateral extent of unconformities

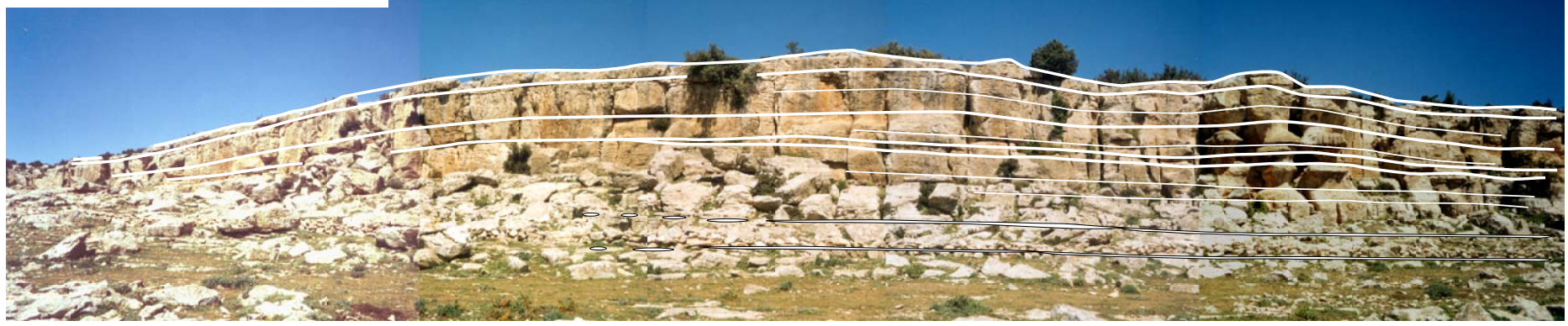

Interpretation

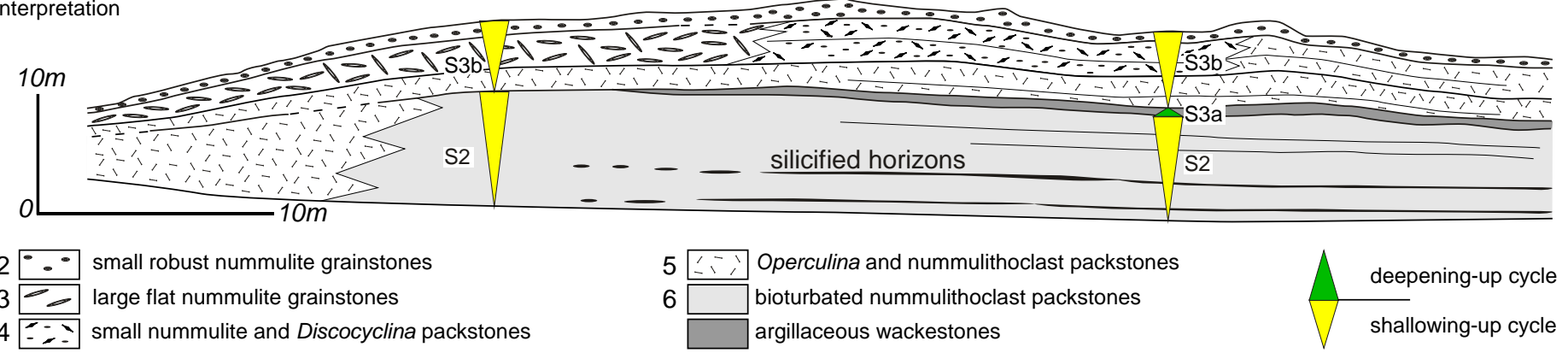




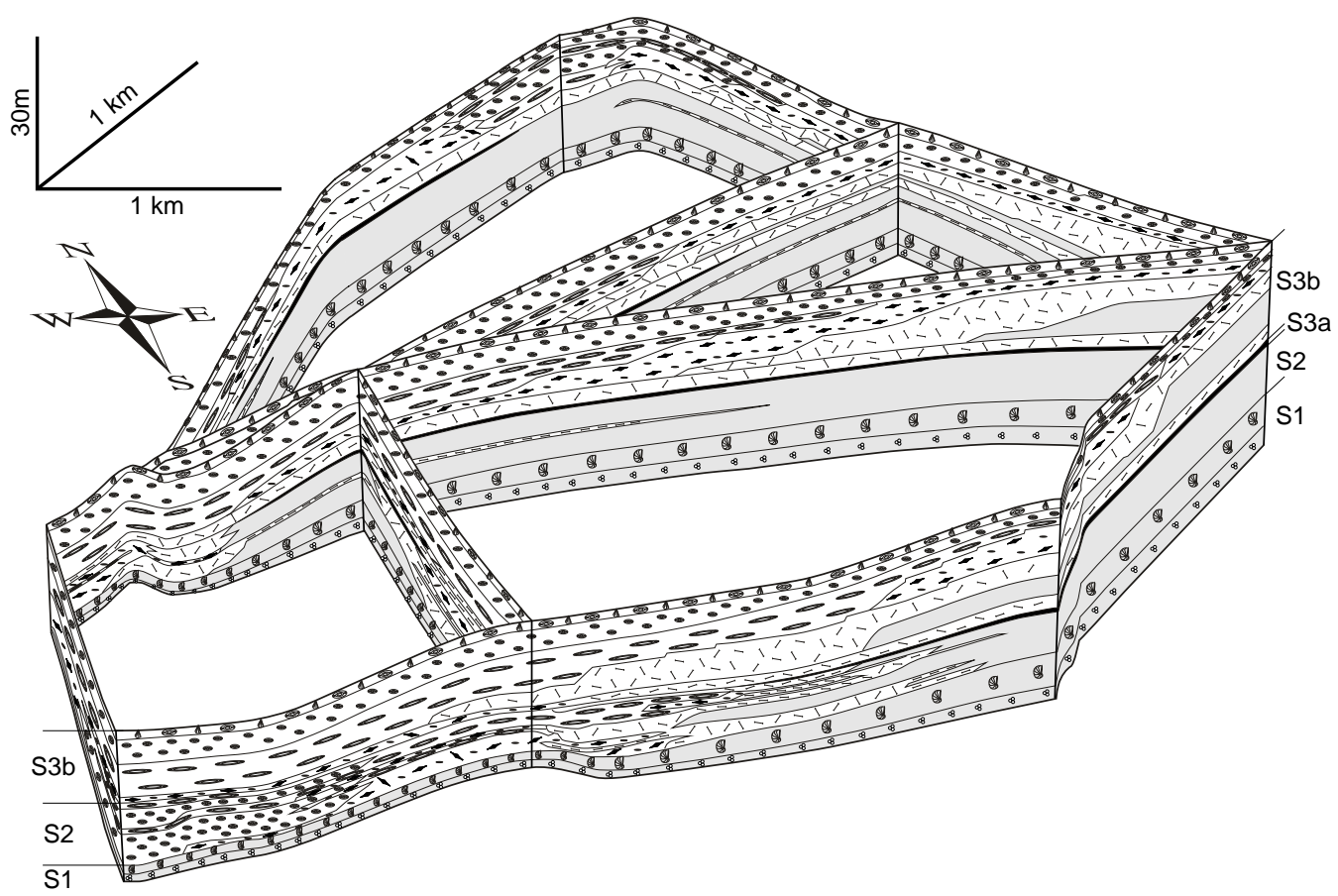

$6 \square$ nummulithoclast packstones

\begin{tabular}{|l|l}
\hline & nummulithoclast packstones \\
& argillaceous wackestones \\
\hline & nautiloid packstones-wackestones \\
\hline & bioturbated glauconitic marls
\end{tabular}

1 large robust nummulite and bivalve grainstones

2 - - small robust nummulite grainstones

3 large flat nummulite grainstones

4 small nummulite and Discocyclina packstones

5 Operculina and nummulithoclast packstones

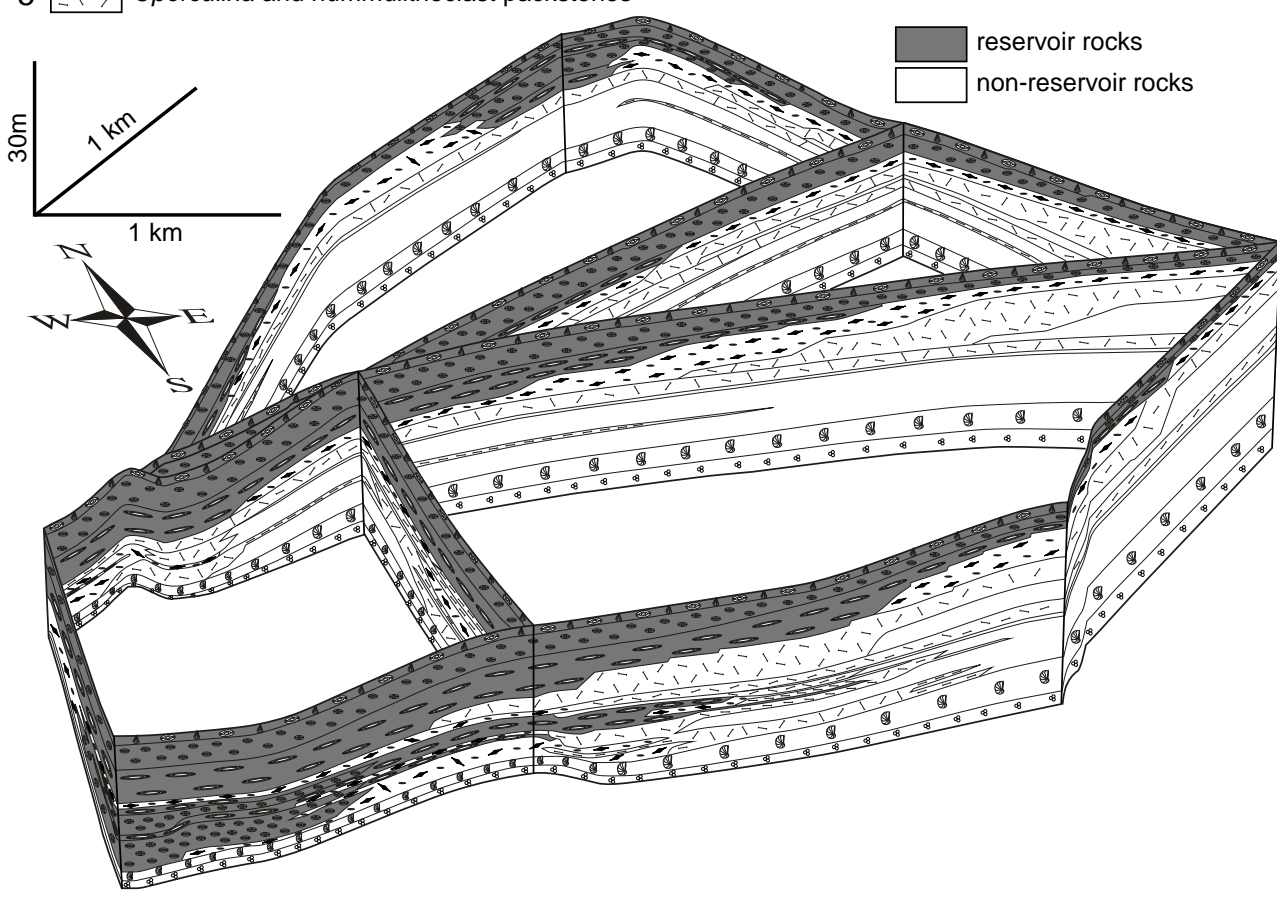




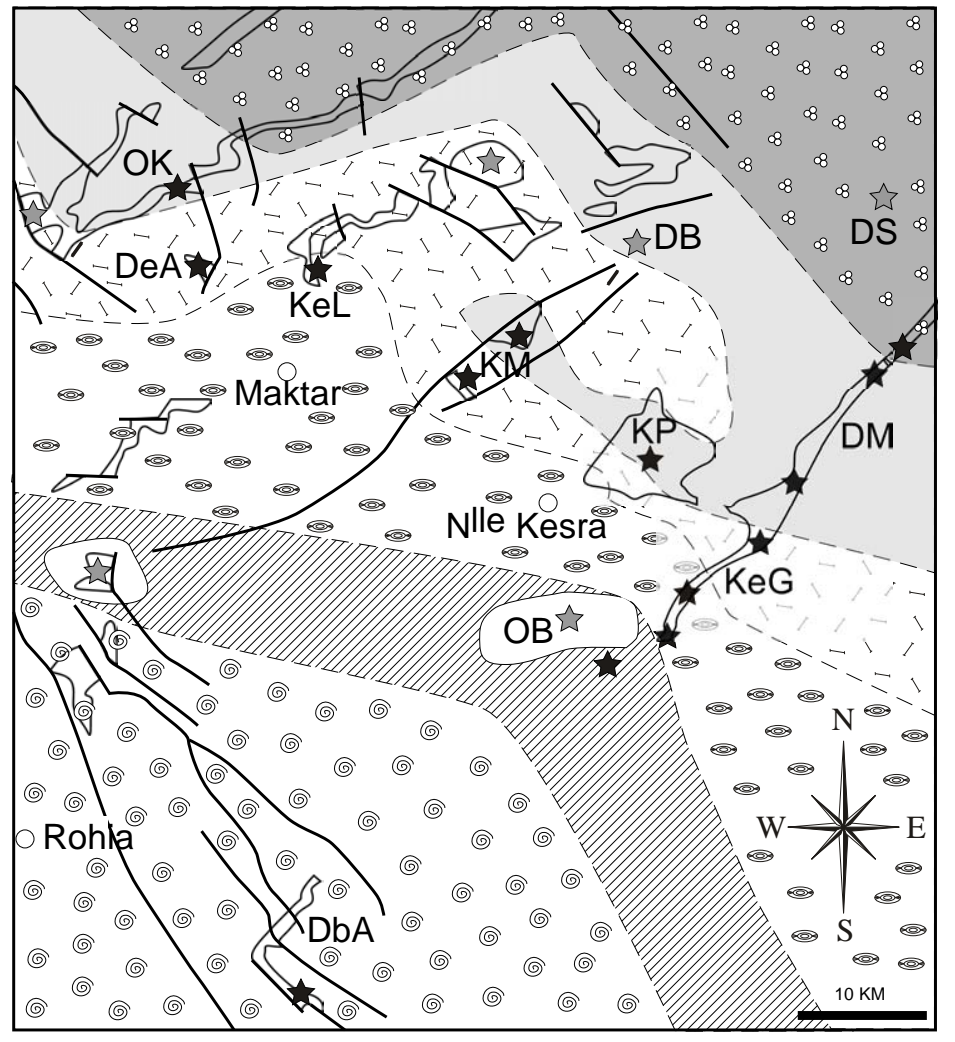

\section{LEGEND}

(ब) (6) gastropod limestone

"bald zone" (topographic high)

nummulite limestone

25: Operculina limestone

nummulithoclast limestone

planktonic foraminifera mud

$\bigcirc$ Upper Ypresian outcrops

fault

- visited outcrop

compiled from : Jauzein, 1967 Rigane, 1991 


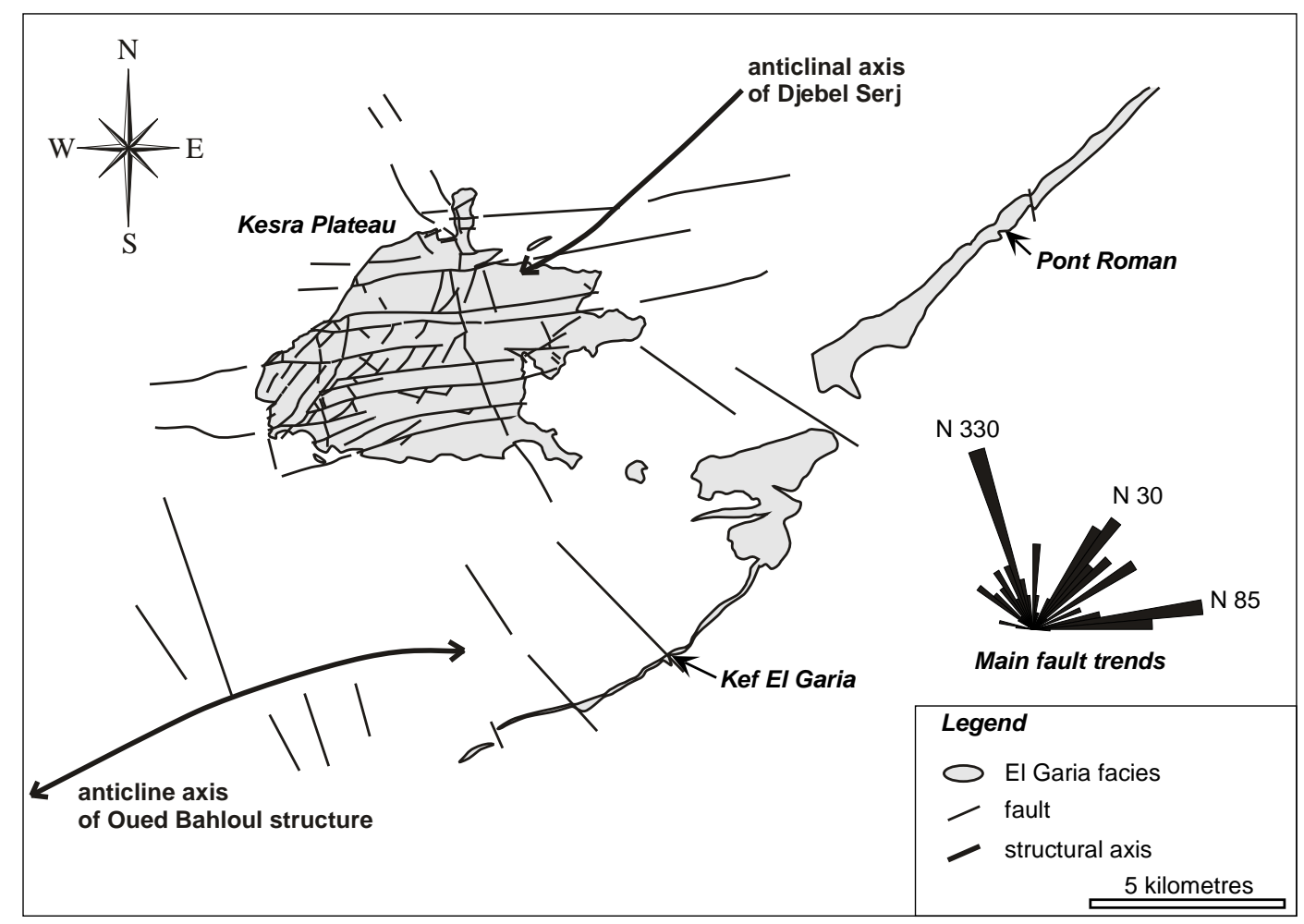



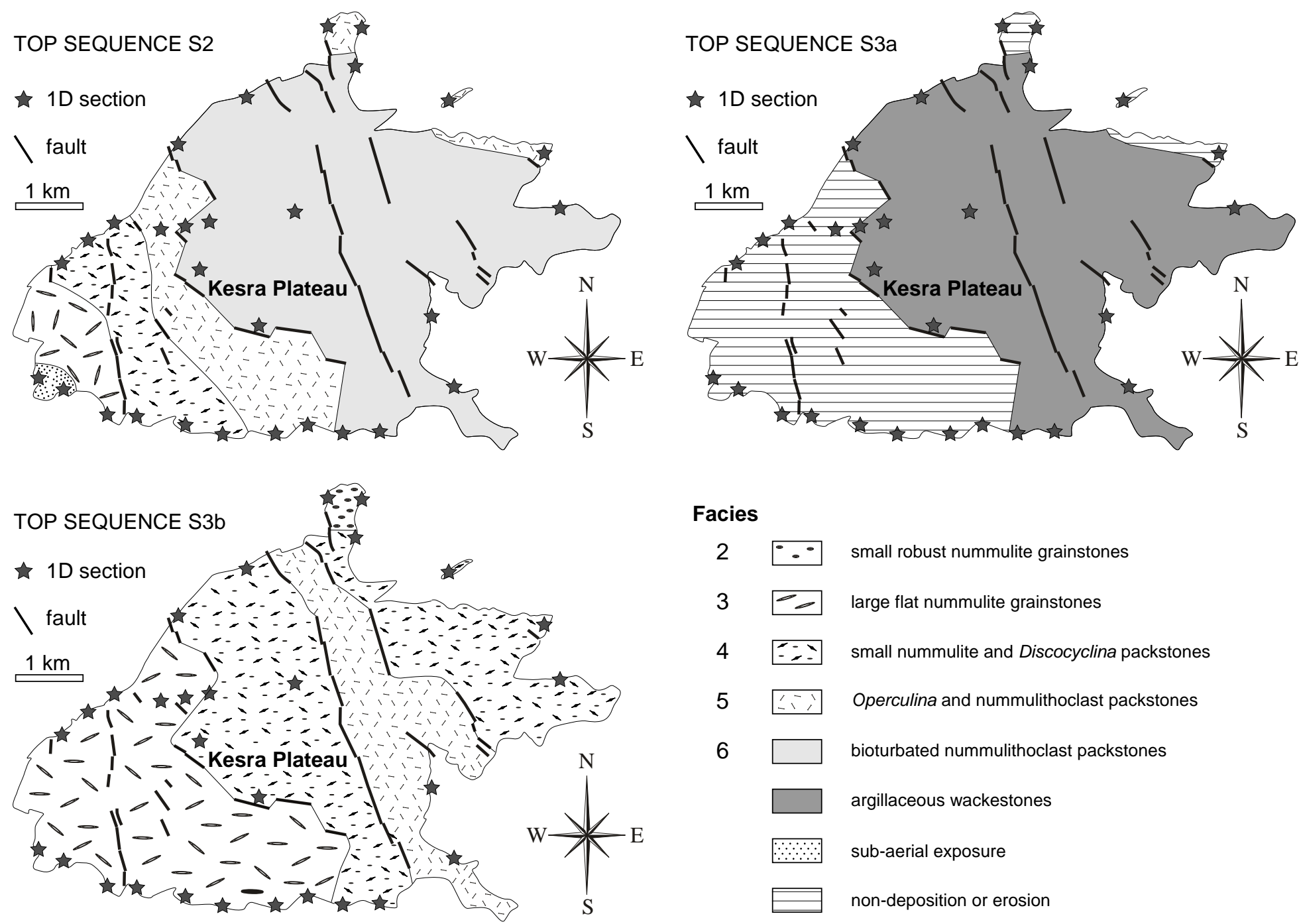

\section{Facies}

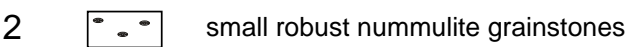
$3 \quad$ large flat nummulite grainstones
4 small nummulite and Discocyclina packstones
5 Operculina and nummulithoclast packstones
$6 \square$ bioturbated nummulithoclast packstones
argillaceous wackestones
sub-aerial exposure
non-deposition or erosion 


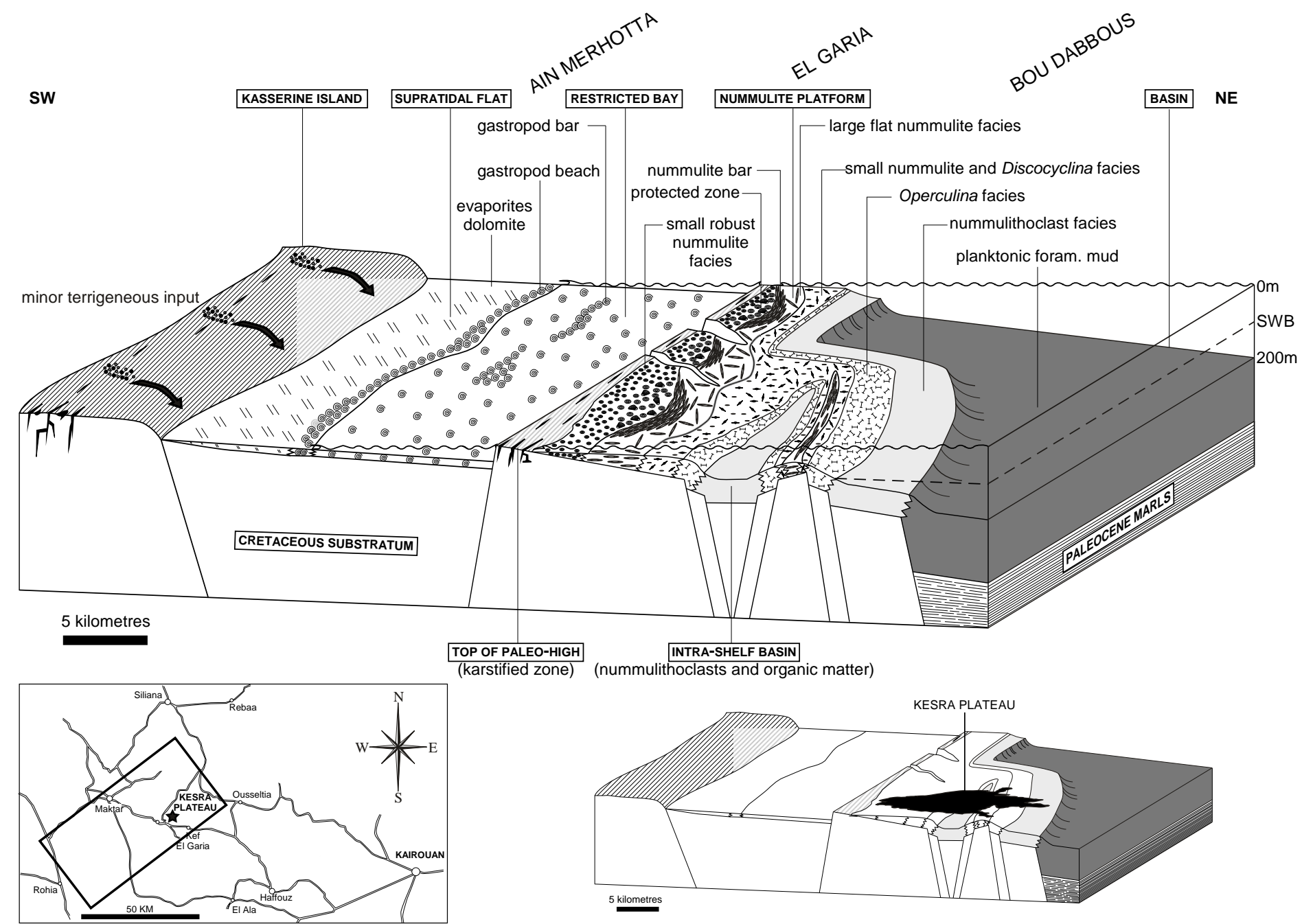

Paleogeographic location of the diagram

Location of the Kesra Plateau on the 3D diagram 